\title{
Treatment for Traumatic Bleeding in Karate Athletes: Cryotherapy X Cryotherapy Associated with Light-Emitting Diode (LED)
}

\section{Paula Carolina Dias Machado* and Hélio Plapler}

Departamento de Cirurgia - Escola Paulista de Medicina - UNIFESP, Disciplina de Técnica de Cirurgia Operatória Experimental, Brazil *Corresponding Author: Paula Carolina Dias Machado Departamento de Cirurgia - Escola Paulista de Medicina - UNIFESP, Disciplina de Técnica de Cirurgia Operatória Experimental, Brazil.

Received: May 13, 2019; Published: June 03, 2019

DOI: $10.31080 /$ ASOR.2019.02.0061

\begin{abstract}
Objective: To evaluate the impact on coagulation time (CT) and relapse index (RI) when using cryotherapy alone or together with a Light-Emitting Diode (LED) to treat acute traumatic bleeding in karate competitors.

Design: The therapeutic approach with low-potency light emission - LED promotes the modulation of some coagulation factors. In martial arts, traumatic bleeding can keep the athletes from returning to the competition.

Methods: 12 karate athletes presenting acute traumatic bleeding were randomly allocated into two treatment groups: A (cryotherapy alone) - three applications of cryotherapy spray for 30seconds with a10-second interval between them and B (cryotherapy + LED) same as group A plus the use of LED on $4 \mathrm{~J} / \mathrm{cm}^{2}$ for 20 seconds. In order to check the immediate effect of the procedure, the coagulation time was measured, according to the Duke's Method (DM). To analyze the late effect we measured the athletes' relapse index RI before the beginning of the subsequent fight (20-25min). Results: in six (100\%) athletes of Group A the bleeding was immediately controlled, whereas only two (33,3\%) athletes in Group B responded positively (DM< 4 min). Five athletes $(83,3 \%)$ in group A presented a new bleeding episode in subsequent fights, but no new bleeding occurred in group B.

Conclusion: Isolated cryotherapy promoted immediate control of bleeding enabling the athlete to return immediately to the competition. Cryotherapy associated with LED was more effective to maintain the clot and prevent new episodes after short break, being more useful if used during the intervals between fights.
\end{abstract}

Keywords: Martial Arts; Laser; Blood Coagulation; Injuries

\section{Introduction}

The practice of direct-contact sports has grown all over the world in the last 10 years, equally for male and female categories [1]. In Brazil, there are approximately 10 thousand karate athletes who practice the Olympic style [2].

The occurrence of severe lesions in karate is not frequent, especially in the Olympic style, named light or semi-contact. Most of the lesions usually considered as mild are contusions, epistaxes and lacerations/abrasions that occur mostly in the face2. However, when these lesions cause bleeding, they can exclude the athlete from the fight, in accordance to the rules $[3,4]$.

Different forms to control traumatic bleeding are used on clinical practice, but it is not described a specific method which stops bleeding fastly and protects the wound even after a new trauma. The most recognized and utilized technique is the compression and application of ice at the wound [5].

The Light Emission Diode (LED) is a well-known dispositive used by dentists, mainly after surgery, for labial ulceration and herpes, being recommended because of its direct effect on blood control, healing and local lymphatic drainage [4]. According to Schubert., et al. [6], the cellular response to photo stimulation is not related to specific properties of laser light. This gave rise to sources of non-coherent light-emitting sources such as the LED. Due to these characteristics more scientific studies, both clinical and experimental, point towards possibilities in which LED and laser may be used for modulation of various biological functions of cells 
and tissues, attesting their potential on the treatment of biological dysfunctions [7].

The LED stimulates the cellular photoreceptors (chromophores), which increases lymphatic circulation and microcirculation. The macrophage and fibroblast activity stimulates cellular tissue and regulates the inflammatory process [7-9]. Benedicente et al [8]. stated that the production of ATP into the mitochondria, along with the ions in the cytoplasm, may increase up to $22 \%$ following low-potency light therapy. Increasing in the production of ATP accelerates cellular division rate, enhancing production of fibroblasts, collagen fibers and neovascularization, promoting better tissue healing and control of tissue disorders [7-9]. As more fibroblasts are released, it stimulates the coagulation cascade cofactors, allowing the production of a fibrin network and its adhesion, leading to a rapid bleeding control [9].

In addition, LED boasts other advantages, such as being a noninvasive technique, without collateral effects. There are few contraindications, its cost is relatively low, potentiates cofactors of the blood coagulation cascade and is efficient for relieving pain and modulating the healing process $[3,4,9]$.

Thus, in sports clinical medicine, the association of cryotherapy and LED irradiation can be very helpful to treat traumatic bleeding lesions.

This study aims to evaluate the efficacy of the spray cryotherapy associated to LED irradiation to control immediate and delayed traumatic bleeding among karate athletes when compared to cryotherapy alone.

\section{Methods}

This is a randomized interventional therapeutic study, approved by the board of São Paulo Karate Federation (FPK). All participants were informed of the objectives of the study and officialized their consent. The study was then performed in three federation's championships between May and June of 2007. This study was approved by the Ethics in Research Committee of São Paulo Federal University under number 0754/09.

The study sample was comprised of athletes of both sex, ages between 12 and 48 years, from different weight categories, distributed among amateurs, experienced fighters and high-level athletes. All of them had to have at least one year of training, no matter the skill level.

Only those individuals with no prior lesions and presentig bleeding laceration or abrasion lesions on any part of the body during the fights were included. Athletes who presented other lacerative or abrasion lesion that could not be considered acute were excluded.

The athletes were directed to the first aid commission, who performed the procedure between the fights, a 15-20 minutes break, or during the interruption of the fight due to the lesion. The lesions were cleaned with antiseptic spray and gauze and photographed.

The athletes were randomly distributed in two groups:

1. Group A - treated exclusively with cryotherapeutic spray: 3 applications of frozen gauze directly in compression way on the lesion for 30 s, with an interval of 10 s between applications. Each application was carried out with a clean gauze.

2. Group B - treated with cryotherapic spray associated with LED irradiation. Cryotherapy was applied as in group A but, immediately after, the LED was applied with its pen wrapped in a PVC foil, directly to the lesion, at the dose of $4 \mathrm{~J} / \mathrm{cm}^{2}$ for $20 \mathrm{~s}$ in each point, with a distance of $1 \mathrm{~cm}$ between the points of application. The number of points was determined by the length and width of each lesion.

After each procedure, lesions were again photographed and the athletes were observed in their subsequent fights. The equipment used was a LED semiconductor device (wavelength of 630+/$10 \mathrm{~nm}$, irradiance of $200 \mathrm{~mW} / \mathrm{cm}^{2}$, MMOPTCS, Sao Paulo, Brazil) and a cryotherapic ICE SPRAY (Ice Spray Max Frio Euroitalia, Nova Ligure, Italy). For local asepsis regular gauzes and a topic antiseptic spray were used. The photographic register was made using a Finepix 2800Zoom, 2.0 Megapixels, 6x optical zoom digital camera.

Three parameters were taken into account to evaluate the procedures:

1. Type of Lesion (TL): The bleeding lesions were classified as abrasion or laceration [10].

2. Coagulation time (CT): The coagulation time scale from the Duke's Method (DM) was chosen to measure the immediate control of bleeding. It determines that a small hemorrhage can be controlled within 2 to 4 minutes. So, if the hemorrhage is not controlled within this time the test is negative for the method. For test positivity, the hemorrhage must cease within 2 to 4 min [10].

3. Relapse Index (RI): the time between the initial treatment and a recurrence of bleeding at the same spot. We've registered as a) if it restarted because of a new trauma, or b) if it restarted spontaneously.

This study was based on acute clinical cases occurred during the event and the measures adopted for the evaluation and collec- 
tion of data were obtained exclusively during the championship (Figure 1-3).

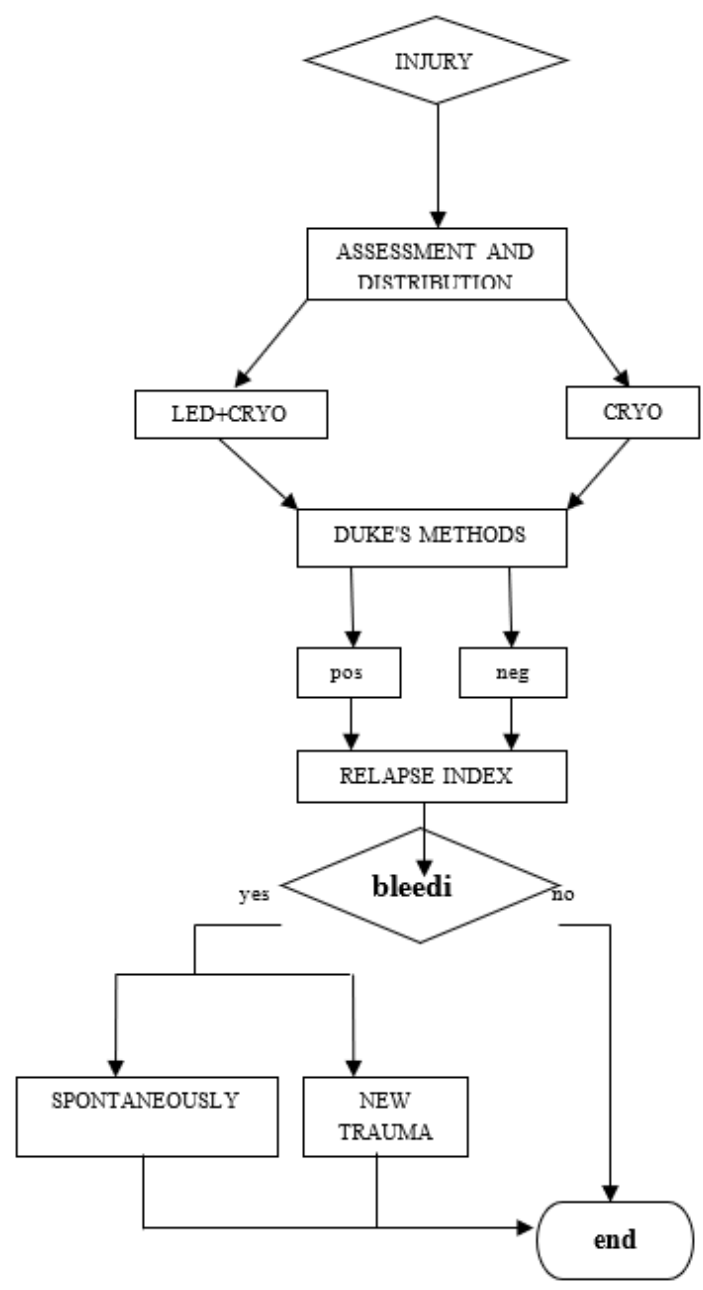

Figure 1: Flowchart of assessment and distribution of groups.

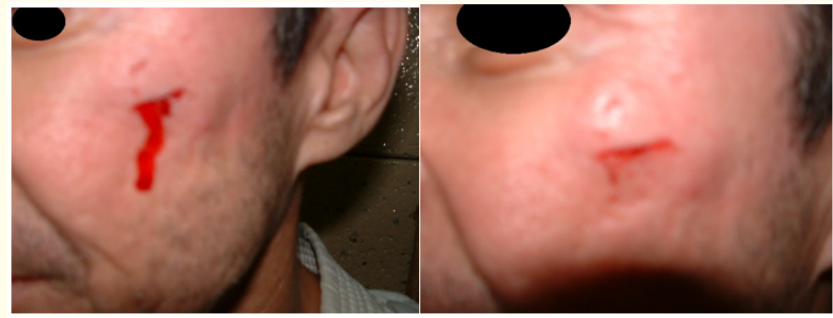

Figure 2: Laceration in zygomatic region before and after the application of cryotherapeutic spray.

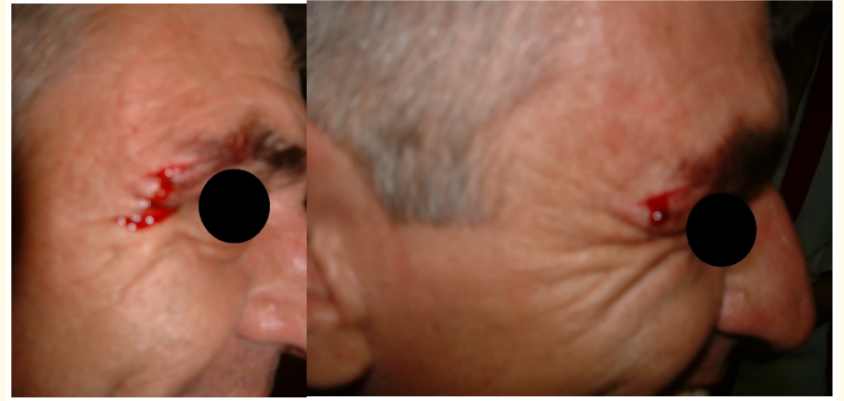

Figure 3: Laceration in superciliary region before and after the application of cryotherapeutic spray and LED.

\section{Results}

Of the 1,450 participants, 23 (1,6\%) presented bleeding lesions but only twelve $(52,2 \%)$ fulfilled the inclusion criteria. Although there was a similar number of male and female athletes, lesions were more prevalent on male participants (10 lesions $=83,2 \%$ ). There were only 2 lesions $(16,7 \%)$ in the female group. The average age was $23.2 \pm 11.55$ years (Table 1 ).

\begin{tabular}{|c|c|c|c|c|}
\hline Variable & $\begin{array}{c}\text { General } \\
(n=12)\end{array}$ & $\begin{array}{c}\text { Group A } \\
(n=6)\end{array}$ & $\begin{array}{c}\text { Group B } \\
(n=6)\end{array}$ & p-Value \\
\hline Age median (SD) & $\begin{array}{c}23.2 \\
(11.55)\end{array}$ & $\begin{array}{c}20.5 \\
(13.58) \\
\end{array}$ & $\begin{array}{c}25.8 \\
(9.60) \\
\end{array}$ & \multirow[t]{2}{*}{$0.310_{(1)}$} \\
\hline Min; $\max$ & $12 ; 48$ & $13 ; 48$ & $12 ; 38$ & \\
\hline \multicolumn{5}{|l|}{ Sex } \\
\hline Female \% (n) & $\begin{array}{l}16,7 \% \\
(2)\end{array}$ & $\begin{array}{c}16,7 \% \\
(1)\end{array}$ & $\begin{array}{c}16,7 \% \\
(1)\end{array}$ & \multirow{2}{*}{$1.000_{(2)}$} \\
\hline Male \% (n) & $\begin{array}{c}83,3 \% \\
(10)\end{array}$ & $\begin{array}{c}83,3 \% \\
(5)\end{array}$ & $\begin{array}{c}83,3 \% \\
(5)\end{array}$ & \\
\hline \multicolumn{5}{|l|}{ Occurrence } \\
\hline Abrasion \% (n) & $\begin{array}{c}33,3 \% \\
(4)\end{array}$ & $\begin{array}{c}33,3 \% \\
(2)\end{array}$ & $\begin{array}{c}33,3 \% \\
(2)\end{array}$ & \multirow{2}{*}{$1.000_{(2)}$} \\
\hline Laceration \% (n) & $\begin{array}{c}66,7 \% \\
(8) \\
\end{array}$ & $\begin{array}{c}66,7 \% \\
(4) \\
\end{array}$ & $\begin{array}{c}66,7 \% \\
(4) \\
\end{array}$ & \\
\hline \multicolumn{5}{|l|}{ Call } \\
\hline $\begin{array}{l}\text { During the fight } \\
\%(\mathrm{n})\end{array}$ & $\begin{array}{c}50,0 \% \\
(6) \\
\end{array}$ & $\begin{array}{c}33,3 \% \\
(2) \\
\end{array}$ & $\begin{array}{c}66,7 \% \\
(4) \\
\end{array}$ & \multirow{2}{*}{$0.567_{(2)}$} \\
\hline $\begin{array}{l}\text { After the fight } \\
\%(\mathrm{n})\end{array}$ & $\begin{array}{c}50,0 \% \\
(6) \\
\end{array}$ & $\begin{array}{c}66,7 \% \\
(4) \\
\end{array}$ & $\begin{array}{c}33,3 \% \\
(2) \\
\end{array}$ & \\
\hline \multicolumn{5}{|c|}{$\begin{array}{l}\text { No differences for p-Value (1)- Mann-Whitney Test; (2)- Fisher's } \\
\text { Exact Test }\end{array}$} \\
\hline
\end{tabular}

Table 1: Distribution of data in studied group. 
The most common lesion in this study was lip laceration, with $50,0 \%$ in each group, followed by lip abrasion, with $16,7 \%$ in each group. The remaining lesions (hand and sole abrasion, zygomatic and superciliary regions lacerations) added up the other 33,3\%. There was no statistical difference between groups regarding the attendance time (Table 2).

\begin{tabular}{|c|c|c|c|}
\hline Variable & Group A $(n=6)$ & Group B $(n=6)$ & p-Value \\
\hline \multicolumn{4}{|l|}{ Duke's Method } \\
\hline Negative \% (n) & $0,0 \%(0)$ & $66,7 \%(4)$ & \multirow[t]{2}{*}{$0.030_{(1)}$} \\
\hline Positive \% (n) & $100 \%(6)$ & $33,3 \%(2)$ & \\
\hline \multicolumn{4}{|l|}{ Relapse Index } \\
\hline Negative \% (n) & $16,7 \%(1)$ & $100 \%(6)$ & \multirow[t]{2}{*}{$0,008_{(1)}$} \\
\hline Positive $\%(\mathrm{n})$ & $83,3 \%(5)$ & $0 \%(0)$ & \\
\hline \multicolumn{4}{|l|}{ Desfeche } \\
\hline \multicolumn{3}{|c|}{ Relapse Index - Negative (no bleeding) } & \\
\hline no trauma \% (n) & $0,0 \%(0)$ & $83,3 \%(5)$ & \multirow[t]{2}{*}{$0.005_{(1)}$} \\
\hline new trauma \% (n) & $16,7 \%(1)$ & $16,7 \%(1)$ & \\
\hline \multicolumn{3}{|c|}{ Relapse Index - Positive (re-bleeding) } & \\
\hline new trauma \% (n) & $33,3 \%(2)$ & $0,0 \%(0)$ & \multirow[t]{2}{*}{$0.005_{(1)}$} \\
\hline spontaneous \% (n) & $50.0 \%(3)$ & $0,0 \%(0)$ & \\
\hline
\end{tabular}

Table 2: Results of DM and RI.

The analysis of coagulation time (CT) and relapse index (RI) was performed using the Exact Fisher's Test One-Tail (Table 2). There was a statistically significant difference between the groups for both CT ( $\mathrm{p}=0.030)$ and $\mathrm{RI}(\mathrm{p}=0.08)$ results (Table 2$)$.

Specifically in Group A, immediate bleeding stop occurred in all patients $(100 \%)$, whereas in Group B, the treatment had only $33,3 \%$ de efficiency regarding the Duke's method.

For the RI results showed that the cryotherapy treatment associated with the LED obtained 100\% efficiency in Group B, none of them presented a re-bleeding. The isolated cryotherapy treatment in Group A was only 16,7\% efficient, as most of them re-bled. Among all the athletes treated, only five presented a relapse, all of them treated only with Cryotherapy; three out of them restarted spontaneously $(60,0 \%)$ and two $(40,0 \%)$ because of a new trauma at the same place of the prior lesion. None in the Group B presented relapse of bleeding, not even one who suffered a new trauma on the same spot of the previous lesion.

\section{Discussion}

According to the studies of Critchley [6] and Merrilee [7], karate still presents a high number of bleeding lesions, even with the use of mouth, hand and foot protectors that have been instituted to protect the athletes. Our data corroborate the findings of Jaffe [8] in their affirmation that male athletes are more prone to suffer lesions. This might be explained by the higher number of male athletes participating in this sport and also by their greater aggressiveness $[3,7,9]$.

We also observed that youngers are more prone to suffer lesions. Nine out of twelve of our lesions occurred in athletes with ages between 12-26 years. Micheli [10], Maffulli [11] and Merrilee [12] also affirm that young athletes in the growth spurt suffer more lesions in the course of training and championships. Others justify this with the lack of experience of the young practitioners [13,16,17].

Our data also found similar incidence with the literature about the most common site of lesion, the face was heat in $75,0 \%$ of the cases [18-20]. Only three athletes had other parts of the body injured [22-24].

In this study, we observed that the cryotherapic spray is the most efficient method to control acute bleeding, but less efficient in maintaining the clot within time. Five out of six lesions in Group A restarted bleeding, three of them spontaneously. As the karate is an activity that keeps high cardiac frequency, the vasodilatation and body heat can rupture the clot [21]. According to Kane et al [10], a lesion that ruptures a vessel associated with a high cardiac frequency makes the bleeding control difficult, whether it is mild or severe. The literature states that even though karate is a sport with interruptions, during the fight or at rest, there is no sufficient time to lower the metabolic and vascular demand. Beneke., et al. [25] states that a high level of metabolic and vascular energy is requested from karate practice's, mostly using an aerobic metabolism. But for energy replenishment high energy phosphates are used through anaerobic metabolism. To achieve this balance, cardiac frequency stays high for long periods. The ice spray acts decreasing very fast the skin temperature and promoting vasoconstriction5. When the athlete returns to activity and increases cardiac frequency, this vasoconstriction effect is interrupted and the bleeding starts again.

We defined as relapse interval the time from initial treatment to the restart of the bleeding. The athletes who were treated by cryotherapy spray and LED didn't have an immediate stop of the blee- 
ding but did not present any relapse during the competition either. This can be explained because the LED promotes a vasodilatation and increases circulation, taking more time to form a clot. But once it is formed, it's harder to rupture. The LED acts in tissue reparation process increasing growing cell factors production, DNA synthesis, mitotic activity, number of fibroblasts, collagen cells and mitochondrial contents [26,27]. For the first 20 seconds after a vascular lesion the cells release some local coagulation factors [10]. One of the most important is TXA-2 which, after being released, initiates a series of events that potentiates platelet signaling and aggregation. TXA-2 initiates the coagulation factors (PDGF among them) signaling process by enhancing the platelets action and adhesion to vascular endothelium for 15 - 20 minutes, controlling local bleeding. LED could release TXA-2 via PDG2-cycloxygenase delaying and prolonging platelets' signaling and migration. On the other hand, this delay may cause massive migration of plasma cells to the site of the wound. Consequently, this signaling becomes more powerful to form the fibrin net, leading to a more vascular resistant clot, with a better and longer control of the bleeding [10].

Regarding to the time of attendance, there was no statistical differences, which shows that this was not a crucial factor to control bleeding.

We could not find any other studies that evaluated the effects of LED on coagulation cascade, neither authors who used it in sports practice, making comparison a hard task.

The most significant clinical finding of this study is that the athlete's traumatic bleeding was controlled for the entire period following the application of the LED.

\section{Conclusion}

In this study the isolated cryotherapic spray proved to be more efficient in the immediate control of traumatic bleeding, as it was able to control the bleeding rapidly. The concomitant use of cryotherapy spray and the LED was more efficient to maintain the clot during the activity.

We suggest the use of cryotherapy during the fight and its association with LED during the intervals to prevent relapse.

\section{Bibliography}

1. "Paulista Karatê Federation". Oficial Report. 5o ed, São Paulo (2007).

2. Jaffe L and Minkoff J. "Martial arts: a perpective on their evolution, injuries, and training formats". Orthopedic Reviews 17.2 (1988): 208-221.
3. Ariza R and Manuel L. "Injury profile in competitive karate: prospective analysis of three consecutive World Karate Championships." Knee Surgery, Sports Traumatology, Arthroscopy 13.7 (2005): 603-607.

4. Lizarelli R. "Dental Clinical protocols: the use of low-intensity laser. 6and rev". São Paulo: Bons Negócios Editora LTDA (2005).

5. Knight KL. "Cryotherapy in Sport Injury Management”. Champaign, IL: Human Kinetics (1995).

6. Schubert EF. "Light emitting diodes". $2^{\underline{a}}$ nd ver. Ed .Cambridge University Press (2006).

7. Nascimento PM. "Effect of stranding of the intensity and wavelength of laser surgery in non-surgical wounds in rats [dissertation]”. São José dos Campos (2001).

8. Benedicente A. "La valutazine dell'incremento de ATP in linfocti sottopsti a biostmulazione con luce laser 904nm infrared". In Atlante di laserterapia. Cuneo, Langa Grafica (1982): 51-57.

9. Alflen TL. "Effect of low level laser (Ga-As-Al) in the prevention of breast fissures in pregnant women [dissertation]". São José dos Campos (2006).

10. Kane A and Kumar V. "Envionmental and nutritional pathology”. In: Robbins Pathologic Basis of Disease”. 6and. ed. São Paulo Guanabara Koogan Company. (2000): 388.

11. Critchley GR., et al. "Injury rates in Shotokan karate". British Journal of Sports Medicine 33.3 (1999): 174-177.

12. Merrilee NZ., et al. "Injuries in martial arts: a comparison of five styles". British Journal of Sports Medicine 39.1(2005): 2933.

13. Claire D., et al. "Incidence and nature of karate injuries". Joint Bone Spine 73.2 (2006): 182-188.

14. Micheli LJ. “The child athlete. In ACSM's Guidelines for the Team Physician". Philadelphia Lea Fabinger (1991): 228-241.

15. Maffulli N and Baxter-Jones AD. "Common skeletal injuries in young athletes". Sports Medicine 19.2 (1995): 137-149.

16. Merrilee NZ., et al.. "Karate injuries in children and adolescents". Accident Analysis and Prevention 32.3(2000): 421-425.

17. Layton C. "Relationship between years of training and judged performance in Shotokan Karate black-belts". Perceptual and Motor Skills 90.1 (2000): 36. 
18. McLatchie GR. "Analysis of karate injuries sustained in 295 contests". Injury 8.2 (1976): 132-134.

19. McLatchie GR. "Prevention of karate injuries, a progress report”. British Journal of Sports Medicine 11.2 (1977): 78-82.

20. McLatchie GR. "Karate and karate injuries". British Journal of Sports Medicine 15.1 (1981): 84-86.

21. Stricevic MV., et al. "Karate: historical perspective and injuries sustained in national and international tournament competition". American Journal of Sports Medicine 11.5 (1983): 320324.

22. Johannsen HV and Noerregaard FO. "Prevention of injury in karate”. British Journal of Sports Medicine 22.3 (1988): 113115.

23. Tuominen R. "Injuries in national karate competition in Finland". Journal of Science and Medicine in Sport 5.1 (1995): 4448.

24. Zetaruk MN., et al. "Karate injuries in children and adolescents". Accident Analysis and Prevention 32.2 (2000): 421-425.

25. Beneke R., et al. "Energetics of Karate kumite". European Journal of Applied Physiology 92.4-5 (2004): 518-523.

26. Pugliese LS., et al. "The influence of Low-Level Laser Therapy on biomodulation of collagen and elastic fibers". Pesquisa Odontológica Brasileira 17.4 (2003): 307-313.

27. Lara RP., et al. "Efecto Morfológico de la Irradiación Láser AsGa en el Músculo Esquelético de Rata”. International Journal of Morphology 25.1 (2007): 43-50.

\section{Volume 2 Issue 7 July 2019}

(C) All rights are reserved by Paula Carolina Dias

Machado and Hélio Plapler. 